\title{
Genetic Structure of Phytophthora infestans Populations in China Indicates Multiple Migration Events
}

\author{
Liyun Guo, Xiao-Qiong Zhu, Chia-Hui Hu, and Jean Beagle Ristaino
}

First and second authors: Department of Plant Pathology, China Agricultural University, Beijing 100193; and third and fourth authors: Department of Plant Pathology, Box 7616, North Carolina State University, Raleigh 27695.

Accepted for publication 12 May 2010.

\begin{abstract}
Guo, L., Zhu, X.-Q., Hu, C.-H., and Ristaino, J. B. 2010. Genetic structure of Phytophthora infestans populations in China indicates multiple migration events. Phytopathology 100:997-1006.

One hundred isolates of Phytophthora infestans collected from 10 provinces in China between 1998 and 2004 were analyzed for mating type, metalaxyl resistance, mitochondrial DNA (mtDNA) haplotype, allozyme genotype, and restriction fragment length polymorphism (RFLP) with the RG-57 probe. In addition, herbarium samples collected in China, Russia, Australia, and other Asian countries were also typed for mtDNA haplotype. The Ia haplotype was found during the first outbreaks of the disease in China (1938 and 1940), Japan (1901, 1930, and 1931), India (1913), Peninsular Malaysia (1950), Nepal (1954), The Philippines (1910), Australia (1917), Russia (1917), and Latvia (1935). In contrast, the Ib haplotype was found after 1950 in China on both potato and tomato (1952, 1954, 1956, and 1982) and in India (1968 and 1974). Another migration of a genotype found in Siberia called SIB-1 (Glucose-6-

haplotype) was identified using RFLP fingerprints among $72 \%$ of the isolates and was widely distributed in the north and south of China and has also been reported in Japan. A new genotype named CN-11 (Gpi 100/111, Pep 100/100, IIb mtDNA haplotype), found only in the south of China, and two additional genotypes (Gpi 100/100, Pep 100/100, Ia mtDNA haplotype) named $\mathrm{CN}-9$ and $\mathrm{CN}-10$ were identified. There were more diverse genotypes among isolates from Yunnan province than elsewhere. The SIB-1 (IIa) genotype is identical to those from Siberia, suggesting later migration of this genotype from either Russia or Japan into China. The widespread predominance of SIB-1 suggests that this genotype has enhanced fitness compared with other genotypes found. Movement of the pathogen into China via infected seed from several sources most likely accounts for the distribution of pathogen genotypes observed. MtDNA haplotype evidence and RFLP data suggest multiple migrations of the pathogen into China after the initial introduction of the Ia haplotype in the 1930 s.
\end{abstract} phosphate isomerase [Gpi] 100/100, Peptidase [Pep] 100/100, IIa mtDNA

Late blight caused by the oomycete pathogen Phytophthora infestans is the most devastating disease of potato in China (54). Late blight occurs in all the major potato-growing regions in China, including the northeast provinces (Heilongjiang, Jilin, Liaoning, and the eastern part of Inner Mongolia), north and northwest China (Inner Mongolia, Gansu, Shaanxi, Ningxia, Shanxi, and Hebei), southwest China (Sichuan, Chongqing, Yunnan, and Guizhou), and south and southeast China (Fujian, Guangdong, and Guangxi). The earliest record of a serious loss caused by late blight in China was in November 1940. More than $90 \%$ of the potato crop was lost in the Chongqing area in that year (53). The first nationwide outbreak of this disease was in the early $1950 \mathrm{~s}$, which led to the intensive investigations of control measures for late blight (57). By using effective fungicides and growing resistant cultivars, late blight was managed in China for nearly three decades, until its reemergence in the early 1990s (57).

P. infestans (Mont.) de Bary is a heterothallic oomycete with two mating types, designated as A1 and A2. The increase of disease occurrence in many countries in the last two decades has been attributed to changes in the genetic structure of pathogen populations (15). DNA evidence suggests that the initial lineage of $P$. infestans introduced to the United States and Europe was the Ia mitochondrial DNA (mtDNA) haplotype and that this haplotype was subsequently replaced by the Ib mtDNA haplotype

Corresponding author: J. B. Ristaino; E-mail address: Jean_Ristaino@ncsu.edu

doi:10.1094/PHYTO-05-09-0126

(C) 2010 The American Phytopathological Society
Additional keywords: genetic diversity, late blight, mtDNA haplotypes.

$(37,41)$. In the mid 1970s, new populations, comprising both the A1 and A2 mating types, were introduced into Europe and the United States from Mexico, and displaced the initial A1 lineages $(15,21)$. New, aggressive genotypes of the pathogen have been found in the United States and Europe (14).

Populations of $P$. infestans have been replaced by more aggressive new strains that often are characterized as A2 mating type and metalaxyl resistant $(10,15)$. The presence of the A2 mating type in China was first reported in 1996 (56). The fungicide metalaxyl was introduced experimentally into China in the late 1980s but used more widely in the 1990s (35). Strains insensitive to metalaxyl were first reported in China in 1998 (34). Subsequently, many investigations on the detection of mating types and fungicide resistance, especially the response to metalaxyl of isolates of $P$. infestans from different geographic regions, have been done $(24,29,32,44,50,51,55,58-60)$. Only a few studies have examined the genetic structure of populations in China $(1,22$, $24,27,32,36,60)$. However, these studies failed to examine the disease on a national scale and did not explore the first introductions of the pathogen or consequences of the migrations due to the lack of historical specimens and reference isolates of known genotypes.

Oospores now play a role in the disease cycle in some areas of Europe and Canada (11). Understanding variation in pathogen populations of $P$. infestans, including the potential for sexual reproduction, is clearly a significant factor in deploying effective control strategies. For example, populations in Scandinavian countries can survive via oospores, and epidemic onset now occurs earlier in the season (5). Populations of $P$. infestans continue to change and late blight management remains a significant challenge to the potato and tomato industry. Little is 
known about the role of sexual reproduction in the pathogen's biology in China (32).

The role of the movement of seed potato tubers in the distribution of pathogen genotypes in the China has not been investigated previously in China but has been studied elsewhere (17). Potato was probably introduced into China in the 17th century (48). Potato was not an important crop under the commune system (1958 to 1978), although peasants were allowed to grow potato for personal consumption. Potato production increased significantly after the 1960s and now China is the largest producer in the world, with over 72 million tons produced in 2007 (13). Potato breeding was done in Inner Mongolia for over 30 years and breeding materials from Russia, South America, and elsewhere were introduced into the country and subsequently moved within China (F. Ezeta and F. Wang, personal communication) (47). Because seed potato tubers are produced in the north of China and are distributed throughout the country, there is the possibility of movement of the pathogen in infested seed (33). Long-distance dispersal of aerial inoculum or movement of seed potato tubers between other Asian countries, including Japan and Russia, could also contribute to epidemic development because shared genotypes have been found among European, Asian, and Russian populations $(3,6,12)$.

An extensive sampling of populations of $P$. infestans collected from potato and tomato fields in 10 provinces in China was conducted in 1998 to 2004. Archival herbarium samples of infected potato leaves were also examined from the first major outbreaks of the disease in China, Russia, and other Asian countries. We studied the phenotypic and genotypic diversity among modern and historic populations of the pathogen in China in order to ask three questions. First, what mtDNA haplotype was first introduced into China? Second, have there been multiple migrations of the pathogen into China? Third, has movement of potato seed affected the population structure of $P$. infestans in China? Preliminary reports of a portion of this work have been published $(27,42)$.

\section{MATERIALS AND METHODS}

Isolates of $\boldsymbol{P}$. infestans. In all, 100 isolates of $P$. infestans from potato $(n=97)$ or tomato $(n=3)$ were collected from 10 provinces in China, including Beijing $(n=3)$, Chongqing $(n=5)$, Fujian $(n=4)$, Gansu $(n=12)$, Hebei $(n=1)$, Heilongjiang $(n=$ $4)$, Jilin $(n=3)$, Inner Mongolia $(n=46)$, Sichuan $(n=10)$, and Yunnan $(\mathrm{n}=12)$, and some isolates were kindly donated by D. L. Liang, A. Ogoshi, W. F. Luo, or C. H. Li (Table 1; Fig. 1) $(26,41,59,60)$. Because sampling was done by many collaborators, sample size is not equal across all provinces and years. Single-zoospore cultures were made and maintained on tomatorye agar which was modified from V8 juice-rye agar (8). Isolates YLM13-5, YLM18-2, and YLM22-4 were single-zoospore isolates of potential self-fertile isolates YLM13, YLM18, and YLM22, respectively. Potential self-fertile isolates formed oospores in low numbers in single culture in the absence of the opposite mating type, as described previously by Fye and Shaw (16). Rye juice was made by soaking $50 \mathrm{~g}$ of rye grain in $1,000 \mathrm{ml}$ of distilled water at $24^{\circ} \mathrm{C}$ for 24 to $36 \mathrm{~h}$ followed by autoclaving for $30 \mathrm{~min}$ and filtering through four layers of cheesecloth. In each liter of the medium, $50 \mathrm{ml}$ of $\mathrm{V} 8$ juice and $0.2 \mathrm{~g}$ of $\mathrm{CaCO}_{3}$ were replaced by $100 \mathrm{ml}$ of tomato juice with $0.4 \mathrm{~g}$ of $\mathrm{CaCO}_{3}$ (25). The final volume was adjusted to $1,000 \mathrm{ml}$ with distilled water. Cultures were maintained at $18^{\circ} \mathrm{C}$ in darkness.

Mating type. The mating type of each isolate was determined by pairing an $\mathrm{A} 1$ tester isolate (DN111) or an A2 tester isolate (DN107) on a block ( $\approx 10$ by 15 by $3 \mathrm{~mm}$ ) of tomato-rye agar with each test isolate $(8,39)$. Tester isolates were kindly provided by A. Ogoshi, Hokkaido University, Japan. An unpaired test isolate was used as a control. Pairings between the opposite mating types of tester isolates was used as a positive control. Five blocks were placed in a petri dish at equal distances from each other along the edge of the petri dish. After incubation at 17 to $19^{\circ} \mathrm{C}$ in darkness for 14 days in a moist chamber, oospore formation on each block was examined microscopically. Isolates that produced oospores with the known A1 tester isolates were designated as the A2 mating type and isolates that produced oospores with the known A2 tester isolate were designated the A1 mating type.

Fungicide sensitivity. The sensitivities of isolates to metalaxyl were tested as described previously (9). The level of sensitivity of each isolate to metalaxyl was determined as described by Shattock (45). Sensitive, intermediate, and resistant phenotypes were defined as isolates exhibiting $<10,10$ to 60 , and $>60 \%$ growth, respectively, on media amended with metalaxyl at $10 \mu \mathrm{g}$ liter ${ }^{-1}$ relative to growth on metalaxyl-free media (Table 2).

DNA extraction. Mycelium of each isolate was obtained by culturing the pathogen for 9 days in darkness at $17^{\circ} \mathrm{C}$ on tomatorye agar overlaid with a cellophane membrane (preboiled in distilled water for $10 \mathrm{~min}$ before autoclaving). Six plates were used for each isolate. The resulting mycelia were then collected from the membranes and stored at $-20^{\circ} \mathrm{C}$. The frozen mycelium $(\approx 350 \mathrm{mg})$ was ground in liquid nitrogen and the genomic DNA was prepared using methods described previously (40). Dried DNA was dissolved in Tris-EDTA containing RNAse overnight at $37^{\circ} \mathrm{C}$, then stored at $-20^{\circ} \mathrm{C}$ before amplification.

mtDNA haplotype analysis. All isolates were analyzed for mtDNA haplotype. Four mitochondrial haplotypes have been described in P. infestans: Ia, Ib, IIa, and IIb $(4,7,23)$. Polymerase chain reactions (PCRs), digestion with restriction enzymes, and determination of haplotypes were according to the methods of Griffith and Shaw (23). The mitochondrial haplotypes of isolates were determined by comparing their patterns to reference isolates of Ia, Ib, IIa, and IIb and by DNA sequencing. The mtDNA haplotypes of samples from archival herbarium collections (Table 3) were determined by PCR amplification and sequencing of smaller targets within the $\mathrm{P} 2, \mathrm{P} 3$, and $\mathrm{P} 4$ regions of the mitochondrial genome by the methods described previously (37). Work with archival materials was done in the Phytotron containment lab at North Carolina State University.

Allozyme analysis. Allozyme genotypes were determined for a subset of isolates at the Glucose-6-phosphate isomerase (Gpi) $(n=48)$ and Peptidase (Pep) $(n=21)$ loci $(20)$. Mycelium obtained from pea broth culture $(120 \mathrm{~g}$ of frozen peas in $500 \mathrm{ml}$ of distilled water, autoclaved for $5 \mathrm{~min}$, filtrate brought to 1 liter, and reautoclaved $25 \mathrm{~min}$ ) was cut into small pieces $\left(0.5\right.$ to $\left.1 \mathrm{~cm}^{2}\right)$ and placed in sterile $1.5-\mathrm{ml}$ microcentrifuge tubes. The mycelium was centrifuged at $13,000 \mathrm{rpm}$ for $1 \mathrm{~min}$ to remove excess water. Extraction buffer $(50 \mu \mathrm{l} ; 20 \%$ sucrose, $2 \%$ Triton X-100, $0.01 \%$ bromophenol blue, and $9.8 \mathrm{ml}$ of $\mathrm{H}_{2} \mathrm{O}$ ) was added to each tube and the mycelia were ground for 30 to $60 \mathrm{~s}$ with a hand drill equipped with sterile Konte pestles. Samples were centrifuged for $2 \mathrm{~min}$ at $10,000 \mathrm{rpm}$, and the supernatant was collected for allozyme analysis.

Allozyme genotypes were determined at the Gpi and Pep loci by cellulose-acetate electrophoresis (CAE) (20). Isolate 188.1.1 of the clonal genotypes US-1 (Gpi 86/100), isolate CR120 of the clonal lineage CR-2 (Gpi 100/111/122), and isolate 94-53 of the clonal genotype US-7 (Gpi 100/111) were used as standards on each acetate plate for the Gpi assay, and 188.1.1 (Pep 92/100) and isolate 93-5 (Pep 100/100) were used as standards for the Pep assay. Isolate $94-53$ was provided by W. Fry, Cornell University. Migration distances of proteins from the unknown isolates were compared with migration distances of proteins from the tester genotypes. Alleles in individual isolates were scored based on the migration of their proteins relative to the protein produced at the 100 allele, which is the most common allele (20).

Restriction fragment length polymorphism genotype. Restriction fragment length polymorphism (RFLP) analysis using 
the RG57 probe was carried out using the methodology described by Goodwin et al. (19) on a subset of isolates $(n=21)$ from China (Table 1). Isolates were grown in pea broth for 14 days at $18^{\circ} \mathrm{C}$. The mycelium was vacuum filtered through Whatman no. 1 filters, lyophilized at $-5^{\circ} \mathrm{C}$ overnight, and ground in liquid nitrogen. Total DNA was extracted following the miniprep procedure described by Lee et al. (31) as modified by Jacobson and Gordon (28). Transfer to Hybond $-\mathrm{N}^{+}$nylon membrane (Amersham Biosciences), hybridization with nonradioactive RG-57 probe, and autoradiography were all according to the manufacturer's instructions (Renaissance nonradioactive kit; NEN Life Science Products, Inc., Boston) and methods described previously (52). The genotype of the isolates was determined by comparing their patterns with those of reference isolates US-1 (188.1.1), US7 (2.1.3), US-8 (94-8-4), and US-15 (80787-94L) (19,21,50).
US1.1 (188.1) and US-7 (2.1.3) were provided by Zamir Punja, University of Vancouver, British Columbia and US-15 (8078794L) was provided by Seong Kim, Pennsylvania Department of Agriculture.

\section{RESULTS}

Of the 100 isolates of $P$. infestans from China, 97 were A1 mating type, with the exception of 3 isolates from Yunnan that were A2 mating type but self-fertile (Table 1). Self-fertile isolates produced a few oospores in single culture but formed more oospores with A1 isolates in crosses.

Metalaxyl resistance was found among the isolates collected (Table 2). Among the 84 isolates tested for resistance to metalaxyl, $42 \%$ were resistant, $33 \%$ were intermediate resistant, and $25 \%$

TABLE 1. Isolates of Phytophthora infestans collected in China and characterized for phenotypic and genotypic traits in this study

\begin{tabular}{|c|c|c|c|c|c|c|c|}
\hline \multicolumn{2}{|l|}{ Field location } & \multirow[b]{2}{*}{ Isolate name ${ }^{\mathrm{a}}$} & \multirow[b]{2}{*}{$\operatorname{Host}^{\mathrm{b}}$} & \multirow[b]{2}{*}{ Sensitivity ${ }^{\mathrm{c}}$} & \multirow[b]{2}{*}{$\mathrm{mtDNA}^{\mathrm{d}}$} & \multirow[b]{2}{*}{ Year $^{\mathrm{e}}$} & \multirow[b]{2}{*}{ Supplier ${ }^{\mathrm{f}}$} \\
\hline Province & County & & & & & & \\
\hline Beijing & Changping & $\mathrm{BC} 1 *$ & $\mathrm{~T}$ & ND & $\mathrm{Ib}$ & 2004 & A \\
\hline Beijing & Daxing & $\mathrm{BT} 02 *, \mathrm{BDX} 4 *$ & $\mathrm{~T}$ & $1 \mathrm{I}, 1 \mathrm{ND}$ & $\mathrm{Ib}$ & 2002 & A \\
\hline Chongqing & Wanxian & CWX3104, CWX4102 & $\mathrm{P}$ & ND & Ia & 2000 & $\mathrm{~B}$ \\
\hline Chongqing & Youyang & CYY1, CYY4 & $\mathrm{P}$ & $\mathrm{S}$ & Ia & 2001 & A \\
\hline Chongqing & Yunyang & CYY $1175^{*}$ & $\mathrm{P}$ & $\mathrm{R}$ & $\mathrm{IIb}$ & 2000 & $\mathrm{~B}$ \\
\hline Fujian & Dehua & FDH10-2, FDH11*, FDH4 & $\mathrm{P}$ & $\mathrm{R}$ & $\mathrm{IIb}$ & 2002 & A \\
\hline Fujian & Zhouning & FZN1-1* & $\mathrm{P}$ & $\mathrm{R}$ & $\mathrm{IIb}$ & 2002 & A \\
\hline Gansu & Huichuan & GHC4 & $\mathrm{P}$ & $\mathrm{S}$ & Ia & 2001 & A \\
\hline Gansu & Lanzhou & GLZ4, GLZ9 & $\mathrm{P}$ & $\mathrm{R}$ & IIa & 2001 & A \\
\hline Gansu & Minxian & GMX10, GMX1-2, GMX17, GMX2-1*, GMX26 & $\mathrm{P}$ & $2 \mathrm{I}, 2 \mathrm{~S}, 1 \mathrm{ND}$ & IIa & 2001 & A \\
\hline Gansu & Minxian & GMX15, GMX19 & $\mathrm{P}$ & $\mathrm{S}$ & Ia & 2001 & A \\
\hline Gansu & Weiyuan & GAN1, GAN1-2 & $\mathrm{P}$ & $1 \mathrm{R}, 1 \mathrm{ND}$ & IIa & 2000 & A \\
\hline Hebei & Weichang & HWCH3* & $\mathrm{P}$ & ND & IIa & 2004 & A \\
\hline Heilongjiang & Harbin & HНB 1, HНB 11, HHB2 $*$, НHB5 & $\mathrm{P}$ & $2 \mathrm{R}, 2 \mathrm{~S}$ & IIa & 2001 & A \\
\hline Inner Mongolia & Baotou & N2396 & $\mathrm{P}$ & $\mathrm{I}$ & IIa & 1998 & $\mathrm{C}$ \\
\hline Inner Mongolia & Baotou & N2397 & $\mathrm{P}$ & $\mathrm{S}$ & IIa & 2000 & $\mathrm{C}$ \\
\hline Inner Mongolia & Hohhot & N2400, N2406, N2431 & $\mathrm{P}$ & 1I, 2ND & IIa & 1998 & $\mathrm{C}$ \\
\hline Inner Mongolia & Hohhot & NHL & $\mathrm{P}$ & $\mathrm{I}$ & IIa & 1998 & A \\
\hline Inner Mongolia & Hohhot & N2398 & $\mathrm{P}$ & I & IIa & 1999 & $\mathrm{C}$ \\
\hline Inner Mongolia & Hohhot & N2338 & $\mathrm{P}$ & I & IIa & 2000 & $\mathrm{C}$ \\
\hline Inner Mongolia & Hohhot & NN15P, NN25, NN26, NN27 & $\mathrm{P}$ & $1 \mathrm{R}, 1 \mathrm{I}, 1 \mathrm{~S}, 1 \mathrm{ND}$ & IIa & 2000 & A \\
\hline Inner Mongolia & Hohhot & $\mathrm{N} 2447, \mathrm{~N} 2451, \mathrm{~N} 2454, \mathrm{~N} 2499, \mathrm{~N} 2511-1 *, \mathrm{~N} 2451-3, \mathrm{~N} 2499-2$ & $\mathrm{P}$ & $5 \mathrm{I}, 2 \mathrm{~S}$ & IIa & 2001 & $\mathrm{C}$ \\
\hline Inner Mongolia & Hohhot & $\mathrm{N} 87110^{*}$ & $\mathrm{P}$ & ND & IIa & 2004 & $\mathrm{C}$ \\
\hline Inner Mongolia & Jiagedaqi & NJQ10, NJQ11, NJQ12, NJQ14, NJQ15, NJQ3, NJQ5, NJQ7, NJQ8 & $\mathrm{P}$ & $\mathrm{R}$ & IIa & 2000 & A \\
\hline Inner Mongolia & Jiagedaqi & N2468 & $\mathrm{P}$ & $\mathrm{R}$ & IIa & 2001 & $\mathrm{C}$ \\
\hline Inner Mongolia & Jining & NJN15, NJN17, NJN18, NJN24, NJN32, NJN33, NJN4, NJN6, NJN7 & $\mathrm{P}$ & $\mathrm{R}$ & IIa & 2001 & A \\
\hline Inner Mongolia & Siziwangqi & NSW1, NSW3, NSW5, NSW6 & $\mathrm{P}$ & I & IIa & 2000 & A \\
\hline Inner Mongolia & WuMeng & $\mathrm{N} 2394$ & $\mathrm{P}$ & I & IIa & 1998 & $\mathrm{C}$ \\
\hline Inner Mongolia & Zhalantun & N2389-2 & $\mathrm{P}$ & $\mathrm{R}$ & IIa & 1999 & $\mathrm{C}$ \\
\hline Inner Mongolia & Zhalantun & NNJ3-1* & $\mathrm{P}$ & $\mathrm{S}$ & IIa & 2000 & A \\
\hline Jilin & Yanbian & JYB1, JYB3* & $\mathrm{P}$ & $\mathrm{R}$ & IIa & 2001 & A \\
\hline Jilin & Yanbian & JYB5 & $\mathrm{P}$ & $\mathrm{R}$ & Ia & 2001 & A \\
\hline Sichuan & Liangshan & SLS4* & $\mathrm{P}$ & $\mathrm{S}$ & $\mathrm{Ib}$ & 2000 & A \\
\hline Sichuan & Liangshan & SLS5, SLS9 & $\mathrm{P}$ & $1 \mathrm{I}, 1 \mathrm{~S}$ & Ia & 2000 & A \\
\hline Sichuan & Sangou & SSG1, SSG3, SSG4 & $\mathrm{P}$ & I & IIa & 2000 & A \\
\hline Sichuan & Shifang & SSF 2, SSF3-1*, SSF8 & $\mathrm{P}$ & $2 \mathrm{~S}, 1 \mathrm{ND}$ & IIa & 2000 & A \\
\hline Sichuan & Shifang & SSF4 & $\mathrm{P}$ & ND & Ia & 2000 & A \\
\hline Yunnan & Ganhaizi & YGHZ1 & $\mathrm{P}$ & ND & IIa & 1999 & A \\
\hline Yunnan & Huize & YPH13-1*, YPH5 & $\mathrm{P}$ & $1 \mathrm{R}, 1 \mathrm{ND}$ & IIa & 1999 & A \\
\hline Yunnan & Kunming & YXSR11 & $\mathrm{P}$ & $\mathrm{S}$ & Ia & 1999 & A \\
\hline Yunnan & Luliang & YLM13-5 $\mathbf{\Delta} *$, YLM18-2 $\mathbf{\Delta}$, YLM22-4 $\mathbf{\Delta} *$ & $\mathrm{P}$ & $\mathrm{I}$ & Ia & 2001 & $\mathrm{D}$ \\
\hline Yunnan & Tonghai & YLT04 & $\mathrm{P}$ & $\mathrm{R}$ & IIa & 1999 & A \\
\hline Yunnan & Tonghai & YLT06 & $\mathrm{P}$ & ND & Ia & 1999 & A \\
\hline Yunnan & Xundian & M-5 & $\mathrm{P}$ & $\mathrm{S}$ & Ia & 2004 & $\mathrm{E}$ \\
\hline Yunnan & Xundian & $\mathrm{XA}-4 *$ & $\mathrm{P}$ & $\mathrm{R}$ & $\mathrm{IIb}$ & 2004 & $\mathrm{E}$ \\
\hline Yunnan & Zhaotong & $\mathrm{Zt}-2-12 *$ & $\mathrm{P}$ & $\mathrm{S}$ & Ia & 2004 & $\mathrm{E}$ \\
\hline
\end{tabular}

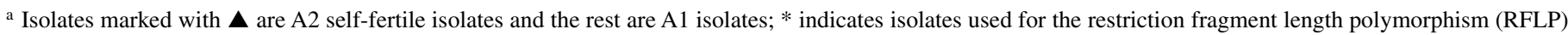
genotype. Isolates from outside China were used as controls in RFLP or allozyme genotype assays.

b $\mathrm{P}=$ potato, $\mathrm{T}=$ tomato,.

c Sensitivity to metalaxyl: ND, not determined; I, intermediate; S, sensitive; R, resistant.

d Mitochondrial DNA.

e Year collected.

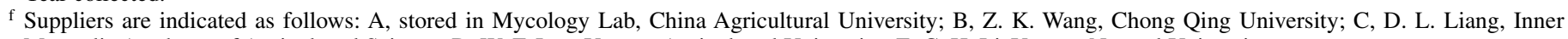
Mongolia Academy of Agricultural Science; D, W. F. Luo, Yunnan Agricultural University; E, C. H. Li, Yunnan Normal University. 
were sensitive. The metalaxyl-resistant isolates were found in populations of $P$. infestans from many provinces, including Chongqing, Fujian, Gansu, Heilongjiang, Inner Mongolia, Jilin, and Yunnan. Sichuan and Beijing provinces were the only provinces where metalaxyl-resistant isolates were not found, although only a few isolates were tested from Beijing. No isolates were tested from Hebei.

The Ia mtDNA haplotype of $P$. infestans was found earlier in China than other mtDNA haplotypes. Samples collected by different researchers in China from tomato in 1938 in Kunming and from potato in 1940 in Chengjiang and Chongqing were the Ia mtDNA haplotype (Table 3). Similarly, the oldest samples from other Asian countries, including India, Japan, Peninsular Malaysia, Nepal, the Philippines, Russia, and Australia, were the Ia haplotype. In contrast, the earliest record of the Ib haplotype of $P$. infestans in China was later: in 1952, on potato in the Sichuan region; in 1954, on potato in Hebei; and in 1956, on tomato in Beijing. The Ib haplotype was also found later in India in 1968 and 1974 (Table 3). Interestingly, the Ib mtDNA haplotype was also found in 1982 on Solanum lyratum in the Sichuan province, documenting a host shift to a wild species (Table 3) (46).

In contrast, four mtDNA haplotypes were detected among modern isolates from potato, including the Ia, Ib, IIa, and IIb haplotypes. The IIa mtDNA haplotype was the most frequent haplotype detected (72\%), followed by the Ia (18\%), IIb $(6 \%)$, and $\mathrm{Ib}(4 \%)$ haplotypes (Table 1$)$. The geographic distribution of the mtDNA haplotypes varied. Both type Ia and IIa mtDNA haplotypes were widely distributed across China, in Gansu, Jilin, Sichuan, and Yunnan provinces (Fig. 1). Only the IIa mtDNA haplotype was detected in Inner Mongolia, Hebei, and Heilongjiang (Fig. 1). In contrast, the distribution of the IIb mtDNA haplotype was limited to the southern part of China, in Chongqing, Fujian, and Yunnan (Fig. 1). The Ib mtDNA haplotype was found both in Sichuan on potato and in Beijing on tomato. DNA sequences from P3 and P4 regions of the mitochondrial genome (data not shown) confirmed the identity of the mtDNA haplotypes.
Four allozyme genotypes, including Gpi 86/100, Pep 92/100; Gpi 86/100, Pep 100/100; Gpi 100/100, Pep 100/100; and Gpi 100/111, Pep 100/100, were found (Fig. 2). Three isolates from tomato and one isolate from potato were either Gpi 86/100, Pep 92/100 or Gpi 86/100, Pep 100/100 and the Ib mtDNA haplotype and identified as the US-1 genotype (21) by RG57 fingerprinting (Table 4). All isolates that were the Ia and IIa mtDNA haplotype were Gpi 100/100, Pep 100/100. Isolates with the IIb mtDNA haplotypes were Gpi 100/111, Pep 100/100 (Table 4).

Variation was observed for the RG57 DNA fingerprint and isolates with unique RFLP fingerprints were observed (Fig. 3; Table 4). Among Gpi 100/100, Pep 100/100 isolates with the Ia mtDNA haplotype, one isolate was a previously described genotype, MO-6 (Moscow-6) (12), and the rest were unique genotypes and named $\mathrm{CN}-9, \mathrm{CN}-9.1$, and $\mathrm{CN}-10$. All isolates with Gpi 100/100, Pep 100/100 allelles and the IIa mtDNA haplotype were

TABLE 2. Relative sensitivity to metalaxyl among isolates of Phytophthora infestans collected from China, 1999-2004

\begin{tabular}{lcccc}
\hline & \multicolumn{3}{c}{ Metalaxyl sensitivity $^{\mathrm{a}}$} & \\
\cline { 2 - 4 } Province & Sensitive & Intermediate & Resistant & Total no. \\
\hline Beijing & - & 1 & - & 1 \\
Chongqing & 2 & 0 & 1 & 3 \\
Fujian & 0 & 0 & 4 & 4 \\
Gansu & 5 & 2 & 3 & 10 \\
Hebei & ND & - & - & 0 \\
Heilongjiang & 2 & - & 2 & 4 \\
Inner Mongolia & 5 & 17 & 20 & 42 \\
Jilin & - & - & 3 & 3 \\
Sichuan & 4 & 4 & - & 8 \\
Yunnan & 3 & 3 & 3 & 9 \\
& 21 & 28 & 35 & 84 \\
\hline
\end{tabular}

a Level of sensitivity of each isolate to metalaxyl was determined as described by Shattock (45). Sensitive, intermediate, and resistant phenotypes were defined as isolates exhibiting $<10,10$ to 60 , and $>60 \%$ growth, respectively, on media amended with metalaxyl at $10 \mu \mathrm{g} \mathrm{liter}^{-1}$ relative to growth on metalaxyl-free media; $-=$ none found and $\mathrm{ND}=$ not determined.

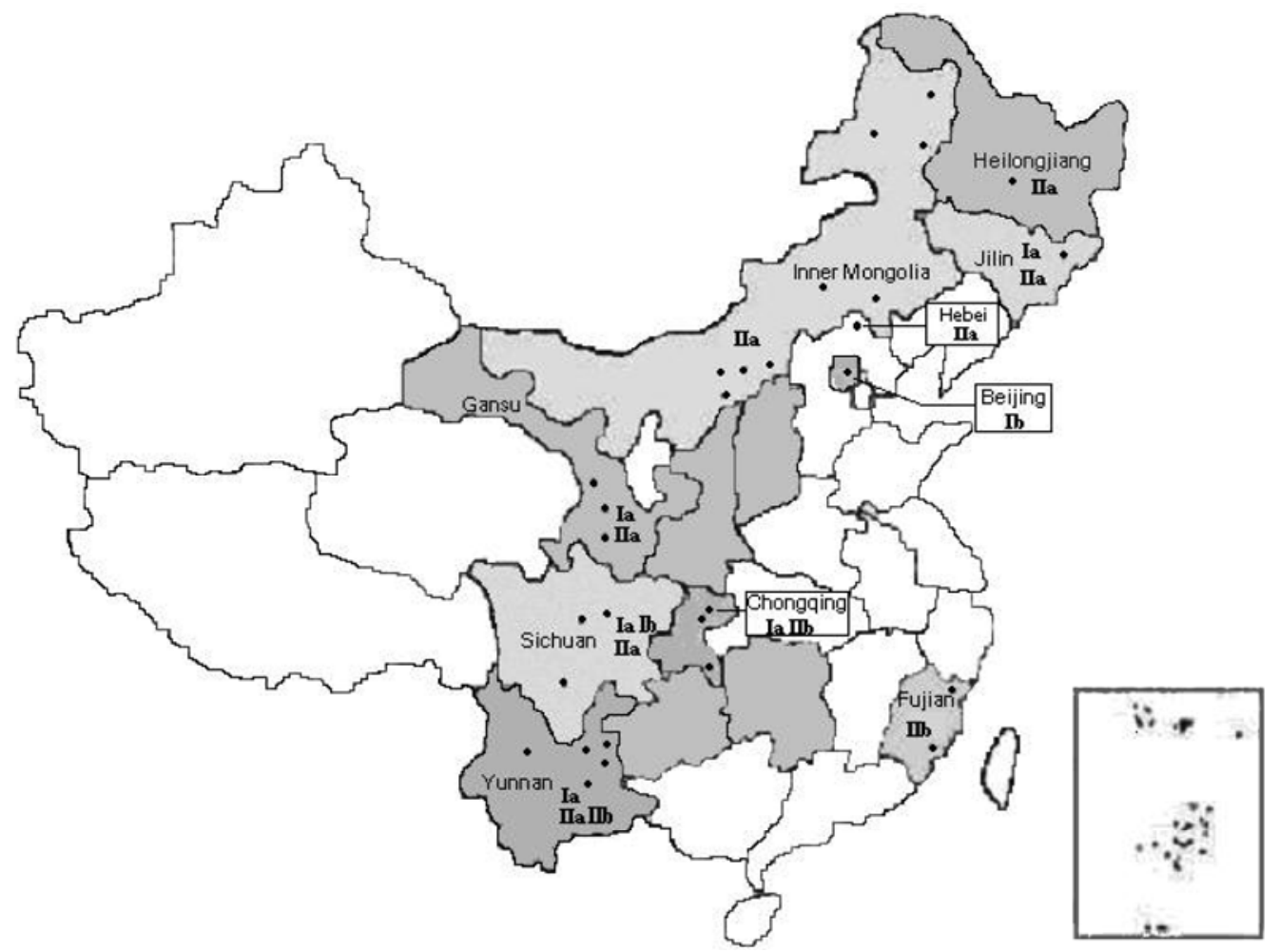

Fig. 1. Sampling locations of Phytophthora infestans and mitochondrial DNA haplotype distribution in major potato production areas in China. 
identified as SIB-1 or variants of SIB-1 (SIB-1.1 or SIB-1.2 that differed by 1 or 2 bands, respectively) (12). Two other isolates were Gpi 100/111 and Pep 100/100, with the IIb mtDNA haplotype and unique RFLP fingerprints, and were named CN-11 and CN-11.1. Two isolates with Gpi 100/111 and Pep 100/100 genotypes and the IIb mtDNA haplotype were identical to the US-16 genotype (or US-16.1) (Table 4).

Among the genotypes found in this study, the levels of resistance to metalaxyl of US-1 isolates varied from sensitive to intermediate resistance. The isolates of $\mathrm{CN}-10$ and MO-6 were sensitive to metalaxyl. Isolates of $\mathrm{CN}-9$ were intermediate. Isolates of $\mathrm{CN}-11$ and US-16 were resistant. The level of metalaxyl resistance among isolates of the SIB-1 genotype varied from sensitive to resistant.

The US-1 genotype was only identified in three isolates from tomato in Beijing and one isolate from potato in Sichuan (Table 4). The predominant genotype was SIB-1 (IIa mtDNA haplotype) and was found in seven provinces in China (Table 4). These isolates were widely distributed in China in Gansu, Hebei, Heilongjiang, Inner Mongolia, and Jilin provinces in the north and Sichuan and Yunnan province in the south (Fig. 1). The $\mathrm{CN}$ 11 genotype was found only in the south of China, in Chongqing and Fujian. The CN-9, CN-10, and MO-6 genotypes were found in Yunnan and the US-16 genotype was also found in Yunnan and Fujian (Table 4). More diverse genotypes were found in Yunnan than other provinces.

A cluster analysis of the genotypes was done with the RFLP data using an unweighted pairgroup method with arithmetic means analysis and NTSYS-PC (43). The dendrogram illustrates the matrices of similarity between the newly described genotypes and other previously reported RFLP genotypes in China (Fig. 4). The SIB-1 genotype is most similar to genotypes reported previously in Japan, including JP-2 and JP-3 and SIB-2 from Japan and Russia, respectively. The previously reported Chinese genotypes $\mathrm{CN}-1$ to $\mathrm{CN}-5, \mathrm{CN}-7$, and $\mathrm{CN}-8$ formed a cluster that was nearest to the new Chinese lineages $\mathrm{CN}-9$ and
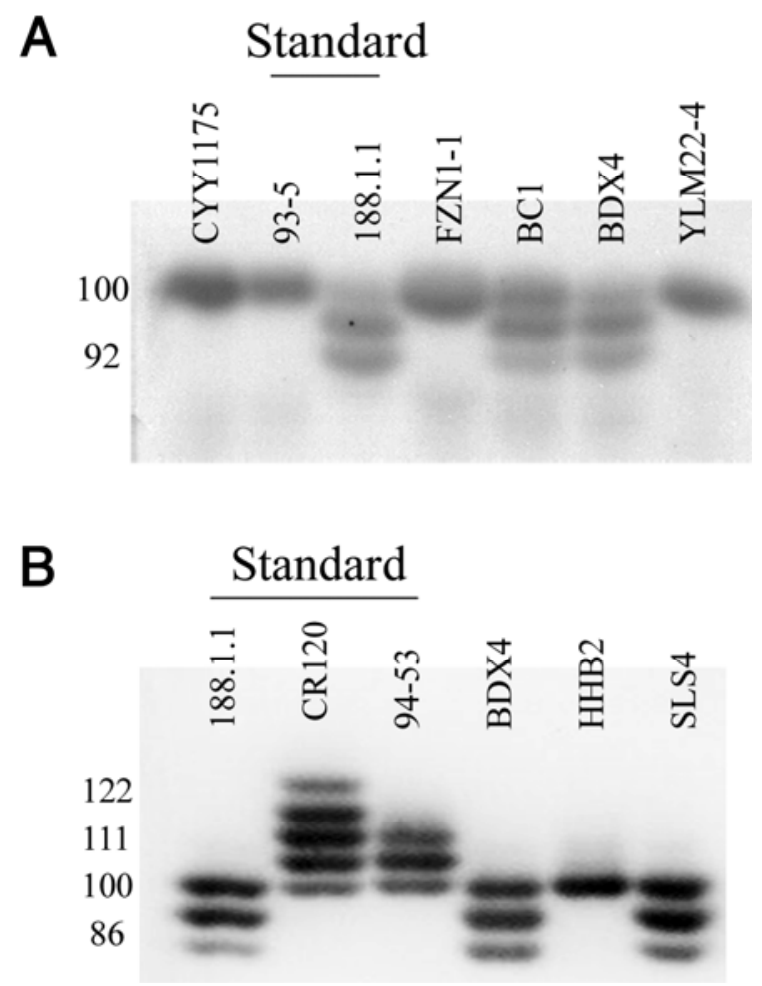

Fig. 2. Allozyme genotypes of Phytophthora infestans on cellulose-acetate gels stained for A, Peptidase (Pep) and B, Glucose-6-phosphate isomerase (Gpi). Pep genotypes of isolates are in lanes 1 to 7 from left to right: Chinese isolate CYY1175 (Pep 100/100), standard US-7 93-5 (Pep 100/100), standard US-1 188.1.1 (Pep 92/100), and Chinese isolates FZN1-1 (Pep 100/100), BC1 (Pep 92/100), BDX4 (Pep 92/100), and YLM22-4 (Pep 100/100). Gpi genotypes of $P$. infestans isolates are in lanes 1 to 6 from left to right: standard US-1 188.1.1 (Gpi 86/100), standard Costa Rican isolate CR120 (Gpi 100/111/122), standard US-7 94-53 (100/111), and Chinese isolates BDX4 (86/100), HHB2 (100/100), and SLS4 (86/100).

TABLE 3. Identity of the mitochondrial DNA haplotypes of Phytophthora infestans in archival herbarium samples from China, southeast Asia, Russia, and Australia, 1901 to 1987

\begin{tabular}{|c|c|c|c|c|c|}
\hline Year & Collector & Country & $\operatorname{Host}^{\mathrm{a}}$ & Collection $^{\mathrm{b}}$ & mtDNA haplotype \\
\hline 1901 & Fukahashi & Japan, Sapporo & S. tuberosum & BPI & Ia \\
\hline 1902 & Unknown & Russia & S. tuberosum & BPI & Ia \\
\hline 1910 & H. S. Yates & Philippines-Luzon & S. tuberosum & BPI & Ia \\
\hline 1913 & J. F. Dastur & India, Bagalphur & S. tuberosum & BPI & Ia \\
\hline 1917 & W. A. Birmingham & Australia, Hurston Park, NSW & S. tuberosum & BPI & Ia \\
\hline 1917 & F. Buchoitz & Russia & S. tuberosum & BPI & Ia \\
\hline \multirow[t]{3}{*}{1930} & Unknown & Japan & S. tuberosum & HMAS & Ia \\
\hline & Unknown & Ukraine & S. tuberosum & BPI & Ia \\
\hline & Unknown & Ukraine & S. tuberosum & BPI & Ia \\
\hline 1931 & K. Togashi & Japan & S. tuberosum & $\mathrm{FH}$ & Ia \\
\hline 1935 & K. Starcs & Latvia & S. tuberosum & BPI & Ia \\
\hline 1938 & C. C. Cheo & China-Yunnan-Kunming & S. tuberosum & HMAS & $\mathrm{Ia}$ \\
\hline 1938 & F. L. Tai & China-Yunnan-Kunming & L. esculentum & HMAS & Ia \\
\hline 1940 & Zhang-xun Heng & China-Yunnan-Chengjiang & S. tuberosum & HMAS & Ia \\
\hline 1940 & Qio Yuan & China-Chongqing & S. tuberosum & HMAS & Ia \\
\hline 1950 & A. Johnston & Peninsular Malaysia & S. tuberosum & $\mathrm{K}$ & Ia \\
\hline 1952 & Zuo-min Yang & China-Sichuan & S. tuberosum & HMAS & $\mathrm{Ib}$ \\
\hline 1954 & He Huang & China-Hebei-Shalingzi & S. tuberosum & HMAS & $\mathrm{Ib}$ \\
\hline 1954 & Stauton & Nepal & S. tuberosum & $\mathrm{K}$ & Ia \\
\hline 1956 & He Huang & China-Beijing & L. esculentum & HMAS & $\mathrm{Ib}$ \\
\hline 1968 & J. A. Russell & India & S. tuberosum & IMI & $\mathrm{Ib}$ \\
\hline 1974 & D. N. Bardoloi & India & S. tuberosum & IMI & $\mathrm{Ib}$ \\
\hline 1981 & R. Black & Thailand & L. esculentum & $\mathrm{K}$ & $\mathrm{Ib}$ \\
\hline 1982 & Qin Yun & China-Sichuan-Yaan & S. lyratum & HMAS & $\mathrm{Ib}$ \\
\hline 1987 & B. C. Sutton & Peninsular Malaysia & L. esculentum & $\mathrm{K}$ & Ia \\
\hline
\end{tabular}

a Lycopersicon esculentum is now called Solanum lycopersicum.

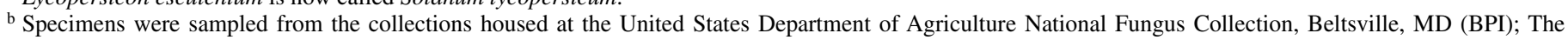
Institute of Microbiology, Chinese Academy of Sciences, People's Republic of China, Beijing (HMAS); the Farlow Herbarium, Harvard University, Cambridge, MA (FH); the Royal Botanic Gardens Mycological Herbarium, Kew, England (K); and the International Mycological Institute, Egham, England (IMI).

${ }^{c}$ Mitochondrial DNA (mtDNA) haplotype determined by the methods of May and Ristaino (37). 
$\mathrm{CN}-10$ and are Ia mtDNA haplotypes. US-16 and $\mathrm{CN}-11$ genotypes were closely related and are IIb mtDNA haplotypes. The US-1 genotypes formed a separate lineage that clustered with MO-6 and $\mathrm{CN}-3$.

\section{DISCUSSION}

Only a few studies have examined the population structure of $P$. infestans in China previously. The US-1 genotype was the only genotype reported in China in a small sample $(n=6)$ of isolates studied in 1994 (36). A comparative study of Japanese $(n=12)$ and Chinese $(n=9)$ populations of $P$. infestans revealed one allozyme genotype (Gpi 100/100 and Pep 100/100) and three RFLP genotypes present in north China in the provinces of Gansu and Hebei in 1996 (1). In that study, a genotype commonly found in Japan called Japanese A1-A (now JP-2) was recognized as similar to a genotype found in Hebei and Gansu called He-Gan A1-A and was a IIa mtDNA haplotype (1). They noted that the same genotype was found in Russia previously and was called SIB-1 $(1,2,12)$. Another study of larger populations $(n=82)$ of $P$. infestans from the four regions of China in Wei Chang, Lanzhou, Kunming, and Chengdu in 1996 and 1997 were the same allozyme genotype (Gpi 100/100 and Pep 100/100) and 8 unique RFLP genotypes were named $\mathrm{CN}-1$ to $\mathrm{CN}-8$ (22). These isolates were all the Ia mtDNA haplotype (22).

Greater genetic variation in populations of $P$. infestans in China was observed in our study than in previous work $(1,2,22$, $32,36,39)$. Four mtDNA haplotypes of $P$. infestans were detected in populations from potato in China (Fig. 1). The Ib mtDNA haplotype was found mostly in Beijing on tomato but was also found in one field on potato in Sichuan. Host adaptation to potato and tomato within the US-1 clonal lineage has been reported previously in Africa and South America. Although we did not examine host adaptation in our work, it is likely that these introductions of $\mathrm{Ib}$ mtDNA haplotype in China may have been from different sources because variants within the US-1 lineage were found (49). In contrast, the other mtDNA haplotypes were geographically separated. Isolates of the IIb mtDNA haplotype were restricted to the south of China in three provinces and the IIb mtDNA haplotypes has also been reported in Taiwan (30), which is close to Fujian province. In contrast, the IIa mtDNA

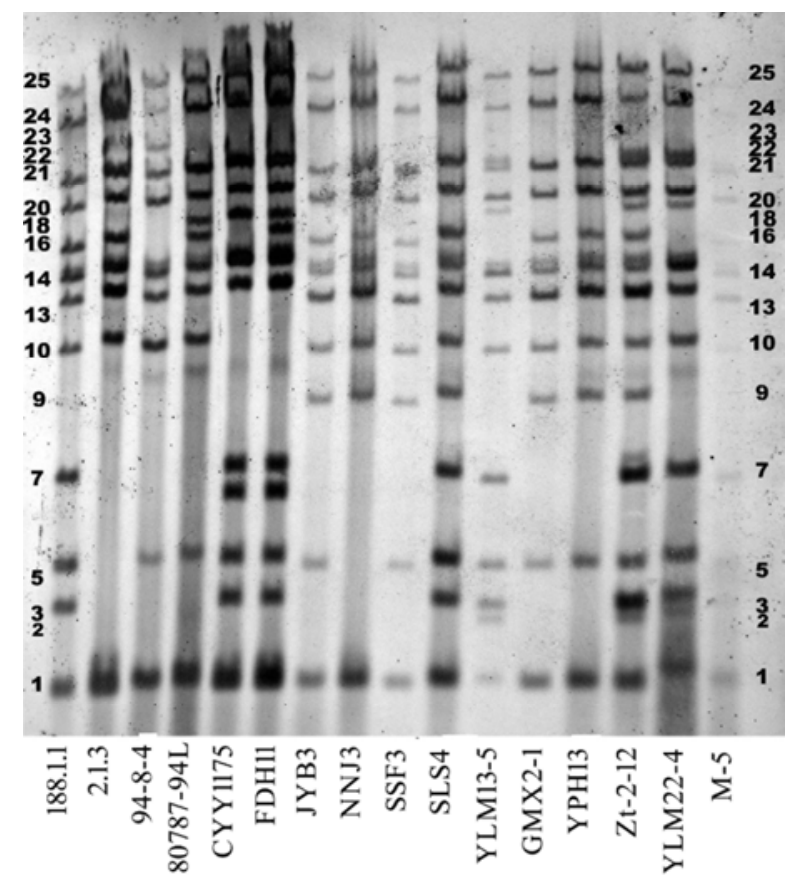

Fig. 3. DNA fingerprint patterns with RG57 probe of Phytophthora infestans. Lane 1, US-1.1 genotype (188.1.1); lane 2, US-7 genotype (2.1.3); lane 3, US8 genotype (94-8-4); lane 4, US-15 genotype (80787-94L); lanes 5 to 16 , Chinese isolate number (genotype) CYY1175 (CN-11), FDH11 (CN-11.1), JYB3 (SIB-1), NNJ3-1 (SIB-1.1), SSF3-1 (SIB-1), SLS4 (US-1.1), YLM13-5 (CN-9.1), GMX2-1 (SIB-1), YPH13-1 (SIB-1), Zt-2-12 (CN-10), YLM22-4 (CN-9), and M-5 (MO-6). RG57 fingerprint band numbers are indicated on the right and left.

TABLE 4. Allozyme genotypes, mitochondrial DNA (mtDNA) haplotype, and restriction fragment length polymorphism (RFLP) fingerprint of Chinese isolates of Phytophthora infestans ${ }^{\mathrm{a}}$

\begin{tabular}{|c|c|c|c|c|c|c|c|c|c|c|c|c|c|c|c|c|c|c|c|c|c|c|c|c|c|}
\hline Province & $\begin{array}{c}\text { Isolate } \\
\text { no. }\end{array}$ & Host & Gpi & Pep & $\mathrm{mtDNA}^{\mathrm{b}}$ & Sens. ${ }^{c}$ & & & & & & & & & & RFL & $P$ fin & ngerp & print $^{c}$ & & & & & & \\
\hline ijing & $\mathrm{BC} 1$ & mato & /100 & /100 & $\mathrm{It}$ & ND & 1 & $\begin{array}{ll}0 & 1\end{array}$ & 10 & 1 & 0 & 1 & 00 & $\begin{array}{ll}0 & 1\end{array}$ & 0 & $\begin{array}{ll}0 & 1\end{array}$ & 1 & $\begin{array}{ll}0 & 1\end{array}$ & 10 & 0 & $0 \quad 1$ & 11 & $\begin{array}{ll}0 & 0\end{array}$ & ) 1 & 1 US- 1.3 \\
\hline ijing & $\mathrm{X} 4$ & mato & 86 & $/ 100$ & $\mathrm{It}$ & ND & 1 & $\begin{array}{ll}0 & 1\end{array}$ & 10 & 1 & 0 & 1 & 00 & $\begin{array}{ll}0 & 1\end{array}$ & 0 & $\begin{array}{ll}0 & 1\end{array}$ & 1 & $\begin{array}{ll}0 & 1\end{array}$ & 10 & 0 & $0 \quad 1$ & 11 & $\begin{array}{ll}0 & 0\end{array}$ & 1 & $1 \mathrm{U}$ \\
\hline & S4 & otato & $86 / 100$ & 0 & $\mathrm{Ib}$ & S & 1 & $\begin{array}{ll}0 & 1\end{array}$ & 10 & 1 & 0 & 1 & $\begin{array}{ll}0 & 1\end{array}$ & 11 & 0 & $\begin{array}{ll}0 & 1\end{array}$ & 1 & $\begin{array}{ll}0 & 1\end{array}$ & 10 & 0 & $\begin{array}{ll}0 & 1\end{array}$ & 11 & $\begin{array}{ll}0 & 0\end{array}$ & ) 1 & $1 \mathrm{U}$ \\
\hline & YLM13-5 & tato & $100 / 100$ & 0 & Ia & I & 1 & 11 & 10 & 1 & 0 & 1 & 00 & $\begin{array}{ll}0 & 1\end{array}$ & 0 & $\begin{array}{ll}0 & 1\end{array}$ & 1 & $\begin{array}{ll}0 & 0\end{array}$ & $\begin{array}{ll}0 & 0\end{array}$ & 1 & $\begin{array}{ll}0 & 1\end{array}$ & 11 & 10 & 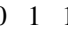 & $1 \mathrm{Cl}$ \\
\hline$n$ & YLM22-4 & Potato & $100 / 100$ & $0 / 100$ & Ia & I & 1 & 11 & 10 & 1 & 0 & 1 & 00 & $\begin{array}{ll}0 & 1\end{array}$ & 0 & $\begin{array}{ll}0 & 1\end{array}$ & 1 & $\begin{array}{ll}0 & 0\end{array}$ & $\begin{array}{ll}0 & 0\end{array}$ & 1 & $\begin{array}{ll}0 & 1\end{array}$ & 11 & $\begin{array}{ll}0 & 0\end{array}$ & 0 & $1 \mathrm{CN}-9$ \\
\hline & M-5 & $\mathrm{P}$ & $100 / 100$ & & Ia & $\mathrm{S}$ & 1 & $\begin{array}{ll}0 & 1\end{array}$ & 10 & 1 & 0 & 1 & 00 & $\begin{array}{ll}0 & 1\end{array}$ & 0 & $\begin{array}{ll}0 & 1\end{array}$ & 1 & $\begin{array}{ll}0 & 1\end{array}$ & 10 & 0 & $0 \quad 1$ & 11 & $\begin{array}{ll}0 & 0\end{array}$ & ) 1 & $1 \mathrm{I}$ \\
\hline 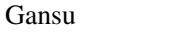 & GMX2- & Potato & /100 & 0 & IIa & ND & 1 & 00 & $\begin{array}{ll}0 & 0\end{array}$ & 1 & 0 & 0 & $\begin{array}{ll}0 & 1\end{array}$ & 11 & 0 & $\begin{array}{ll}0 & 1\end{array}$ & 11 & $\begin{array}{ll}0 & 1\end{array}$ & 10 & 0 & $\begin{array}{ll}0 & 1\end{array}$ & 11 & $\begin{array}{ll}0 & 0\end{array}$ & 0 & $1 \mathrm{~S}$ \\
\hline & $V C$ & Potato & & & IIa & ND & 1 & 00 & $\begin{array}{ll}0 & 0\end{array}$ & 1 & 0 & 0 & $\begin{array}{ll}0 & 0\end{array}$ & $\begin{array}{ll}0 & 1\end{array}$ & 0 & $\begin{array}{ll}0 & 1\end{array}$ & 1 & $\begin{array}{ll}0 & 1\end{array}$ & 10 & 0 & $\begin{array}{ll}0 & 1\end{array}$ & 11 & $\begin{array}{ll}0 & 1\end{array}$ & 11 & 1.2 \\
\hline & & & & & II & $\mathrm{R}$ & 1 & 00 & $\begin{array}{ll}0 & 0\end{array}$ & 1 & 0 & 0 & $\begin{array}{ll}0 & 1\end{array}$ & 11 & 0 & $\begin{array}{ll}0 & 1\end{array}$ & 1 & $\begin{array}{ll}0 & 1\end{array}$ & 10 & 0 & $0 \quad 1$ & 11 & $\begin{array}{ll}0 & 0\end{array}$ & $\begin{array}{l}0 \\
0\end{array}$ & 1 \\
\hline & 51 & to & 0 & & II & I & 1 & 00 & $\begin{array}{ll}0 & 0\end{array}$ & 1 & 0 & 0 & $\begin{array}{ll}0 & 1\end{array}$ & 11 & 0 & $\begin{array}{ll}0 & 1\end{array}$ & 1 & $\begin{array}{ll}0 & 1\end{array}$ & 10 & 0 & $0 \quad 1$ & 11 & $\begin{array}{ll}0 & 0\end{array}$ & $\begin{array}{l}0 \\
0\end{array}$ & $1 \mathrm{~s}$ \\
\hline & 3711 & Potato & & & 11 & ND & 1 & 00 & $\begin{array}{ll}0 & 0\end{array}$ & 1 & 0 & 0 & $\begin{array}{ll}0 & 0\end{array}$ & $\begin{array}{ll}0 & 1\end{array}$ & 0 & $\begin{array}{ll}0 & 1\end{array}$ & 11 & $\begin{array}{ll}0 & 1\end{array}$ & 10 & 0 & $0 \quad 1$ & 11 & $\begin{array}{ll}0 & 1\end{array}$ & 11 & 1.2 \\
\hline 1101 & NNJ3-1 & Potato & $/ / 100$ & & $\mathrm{IIa}$ & $\mathrm{C}$ & 1 & 00 & $\begin{array}{ll}0 & 0\end{array}$ & 0 & 0 & 0 & $\begin{array}{ll}0 & 1\end{array}$ & 11 & 0 & $\begin{array}{ll}0 & 1\end{array}$ & 11 & $\begin{array}{ll}0 & 1\end{array}$ & 10 & 0 & $\begin{array}{ll}0 & 1\end{array}$ & 11 & $\begin{array}{ll}0 & 0\end{array}$ & 0 & -1.1 \\
\hline & SSF3-1 & Potato & & & IIa & & 1 & $0 \quad 0$ & $\begin{array}{ll}0 & 0\end{array}$ & 1 & 0 & 0 & $\begin{array}{ll}0 & 1\end{array}$ & 11 & 0 & $\begin{array}{ll}0 & 1\end{array}$ & 1 & $\begin{array}{ll}0 & 1\end{array}$ & 10 & 0 & $0 \quad 1$ & 11 & $\begin{array}{ll}0 & 0\end{array}$ & ) 1 & -1 \\
\hline Yunnan & XA-4 & Potato & $100 / 111$ & $100 / 100$ & IIb & & 1 & & & & & & & & & & & & 10 & 1 & $\begin{array}{ll}0 & 1\end{array}$ & 11 & $\begin{array}{ll}0 & 0\end{array}$ & & 1 US-16 \\
\hline
\end{tabular}

${ }^{a}$ Genotype identified by mating type, allozyme analysis at glucose-6-phosphate isomerase (Gpi) and peptidase (Pep) loci, and mtDNA haplotype and RFLP fingerprint (19).

${ }^{\mathrm{b}}$ MtDNA haplotype determined by the methods of Griffith and Shaw (23).

${ }^{\mathrm{c}}$ Sensitivity to metalaxyl: ND, not determined; I, intermediate; S, sensitive; R, resistant.

${ }^{\mathrm{d}}$ Presence (1) or absence (0) of RG57 fingerprint bands. Bands 1 to 25 are indicated from left to right. Band 4 did not appear in isolates tested and is not diagnostic. Genotypes US-1.1, US-1.3, US-16 (21), MO-6, and SIB-1 (12) and CN-1 to CN-8 (22) were described previously. The genotypes CN-9, CN-9.1, CN$10, \mathrm{CN}-11, \mathrm{CN}-11.1 \mathrm{US}-16.1$, and SIB-1.2 are named here. 
haplotype was more widely distributed than reported previously (1), and found in seven provinces in China. Other investigations have also reported the IIa mtDNA haplotype (SIB-1) in several countries, including Japan, Korea, and Russia $(1,2,12)$, but this haplotype has not been reported in countries south of China. Likewise, the Ia mtDNA haplotype was widely distributed in five of eight provinces. In India and Nepal, the Ia haplotype is dominant and has been present in these countries since at least 1913 and 1954, respectively (Table 3) (17,22). Because late blight was only reported in the 20th century in China and China is far from the center of origin of late blight pathogen (18), the presence of all four mtDNA haplotypes of the pathogen and their spatial distribution in China in different regions suggests that the pathogen was probably introduced into China from multiple sources at different times. Clearly, the earliest introductions of $P$. infestans into China included Ia mtDNA haplotypes. More and different mtDNA haplotypes were found in Yunnan province, where multiple sources of seed potato have been introduced from both the north and south of China in recent years (Fig. 5).

Data from the archival herbarium samples supports the hypothesis of multiple migrations of $P$. infestans into China and also suggests the time periods when these migrations occurred. The Ia mtDNA haplotype of $P$. infestans was found earlier in China than other mtDNA haplotypes. Samples collected by different researchers in China from the first outbreaks from tomato in 1938 in Kunming and from potato in 1940 in Chengjiang and Chongqing were the Ia mtDNA haplotype. In contrast, the earliest record of the Ib haplotype (US-1 genotype) of $P$. infestans in China was in 1952 on potato in the Sichuan region, in 1954 on potato in Hebei, and in 1956 on tomato in Beijing. In samples from other Asian countries (India, Japan, Peninsular Malaysia, Nepal, and
The Philippines), the Ia mtDNA haplotype was also found earlier than the Ib haplotype. Our current data indicate that the Ia haplotype is present in five of the eight provinces sampled in China (Table 1; Fig. 1). The Ia haplotype was most likely the founder haplotype introduced into China and the $\mathrm{Ib}$ mtDNA haplotypes migrated later in the mid-20th century, refuting other reports of the Ia displacing the "old" Ib populations in this region $(14,17)$. There were multiple introductions of the Ia mtDNA haplotypes into other Asian countries (Table 3). We cannot rule out multiple introductions of the Ia haplotype into China. The expanded number of RFLP genotypes that are Ia haplotypes suggest that this may be the case (22). We previously documented that the $\mathrm{Ia}$ and $\mathrm{Ib}$ mitochondrial lineages arose independently and that the Ib is not derived from the Ia (4). Our data suggest a postWWII spread of the Ib mtDNA haplotype into Asia, most likely from South American seed potato, and could explain previous reports of its widespread occurrence in the 1970s to $1990 \mathrm{~s}$ worldwide $(14,15,21)$.

Interestingly, the Ib mtDNA haplotype was also found in 1982 on S. lyratum, an herbaceous species that grows wild throughout China and Asia adjacent to cultivated fields (Table 3). This represents an example of a host shift for the pathogen to a related wild species (46). Because the US-1 genotype (Ib mtDNA haplotype) is highly sensitive to the fungicide metalaxyl in some areas of the world $(10,21,45)$, perhaps $S$. lyratum acted as a reservoir for the metalaxyl-sensitive genotype to survive in a wild, unsprayed host and then spread into cultivated potato or tomato. Although populations of US-1 in North America are sensitive to metalaxyl, South African populations have developed resistance to phenylamides (45). It would be interesting to survey $S$. lyratum in China for the presence of $P$. infestans and test isolates

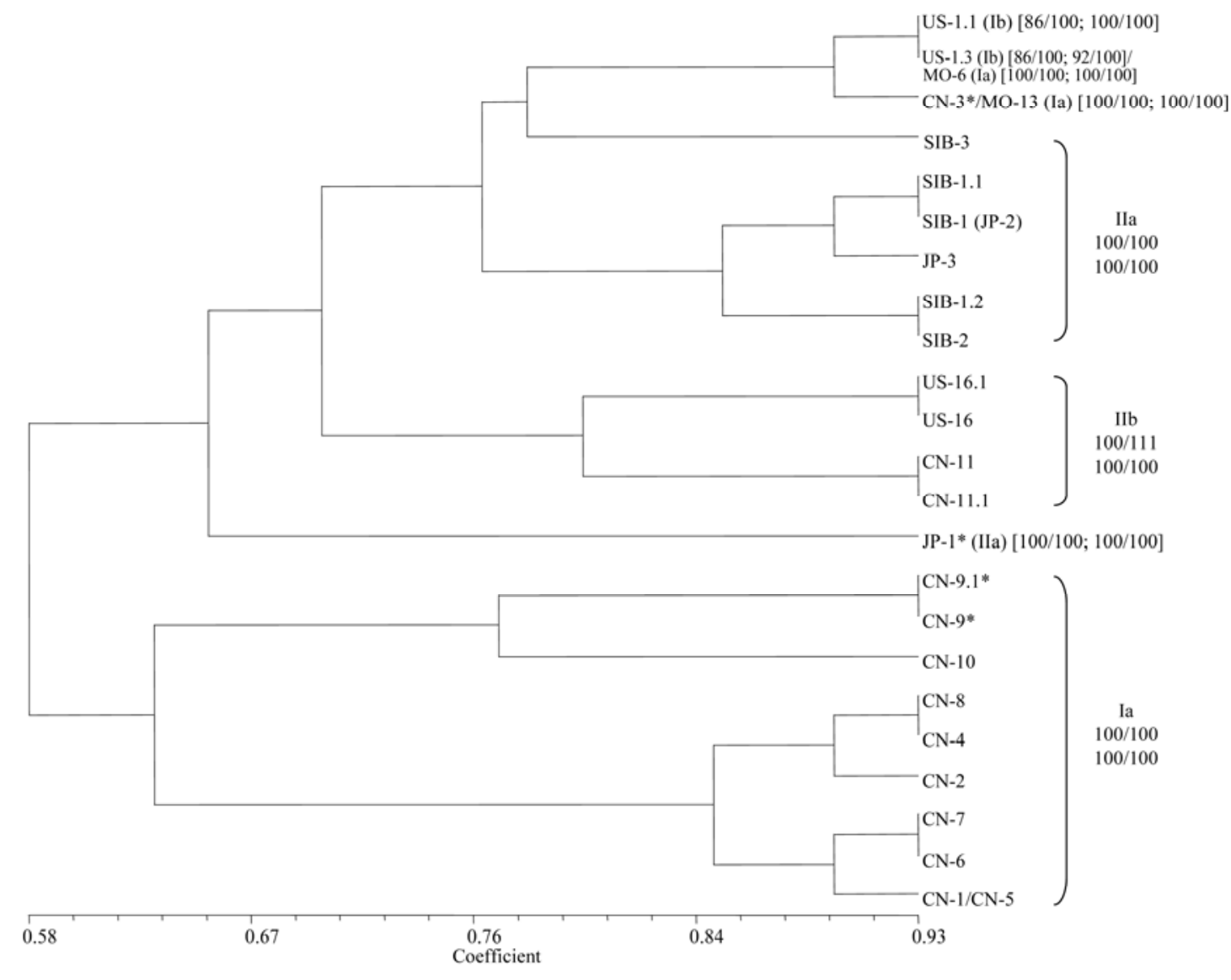

Fig. 4. Dendrogram of newly described Chinese restriction fragment length polymorphism genotypes and previously reported genotypes of Phytophthora infestans based on matrices of similarity using unweighted pairgroup method with arithmetic means analysis in NTSYS-PC (43). Asterisks indicate A2 mating types. Similarity coefficient shown at the bottom of the figure. 
recovered for genotype and sensitivity to metalaxyl to confirm or refute this hypothesis.

Previous workers have described eight RFLP genotypes of $P$. infestans in China, including $\mathrm{CN}-1$ to $\mathrm{CN}-8$ (22). Our findings suggest that the genetic diversity of $P$. infestans populations in China is greater than previously detected. Seven RFLP genotypes, including US-1 (21), US-16 (21), MO-6 (12), SIB-1 (12), and the three newly named genotypes $\mathrm{CN}-9, \mathrm{CN}-10$, and $\mathrm{CN}-11$, were identified. The genotype SIB-1 was the most predominant genotype detected among the isolates we tested and was widely distributed in both the north and south in China in seven provinces. SIB-1 may have fitness traits that have led to its widespread adaptation in China, similar to US-8 in the United States and Blue 13 in Europe, and this possibility needs further examination (14). SIB-1 was also reported as the dominant genotype in Siberia and the Russian Far East Sakhalin Islands in another study (12). The spatial distribution of SIB-1 in Russia suggests that the genotype was most likely spread via the trans-Siberian railway because this is a common method of transporting potato tubers in Russia (12). Potato tubers were introduced from Russia into China through collaboration and nongovernmental trade (Fig. 5) in the north of China in Helongjiang and also in the south to Yunnan in 1950s $(33,47,48)$.

The most predominant RFLP genotype identified in our study was SIB-1. This genotype is also called Japanese A1-A and JP-2 in Japan (22). SIB-1 has also been found in Russia and some other European countries (22), which suggests several possible migrations pathways of this clonal lineage into China from other neighboring countries, including Siberia or Japan. The cluster analysis also indicated a close relationship between SIB-1, JP-2, and JP-3. SIB-1 is widely distributed within China from the north to the south, likely as a result of migration of the late blight pathogen within seed tubers (60) (Fig. 5). Historical movement of potato tubers as breeding materials from outside China and from north China to Yunnan has been documented (60). From the late 1950s to 1990, several hundred potato breeding lines, including both local cultivars and cultivars from outside China and from the International Potato Center, were collected and planted in the experimental plots of Wumeng Agricultural Institute, Inner Mongolia for breeding purposes (60). Some of this breeding material was later introduced into Yunnan, Guizhou, and Sichuan. The experimental plot of Wumeng Agricultural Institute, Inner Mongolia was one of the places that the A2 mating type was first detected in China (56).

Before mid-1980s, farmers in China used to use potato tubers from the previous year's crop as seed tubers, until yields declined due to the accumulation of tuberborne viruses. In the late 1980s, techniques for growing virus-free tubers were adopted in China and a majority of the base for "virus-free seed potato tubers" was set up in the northern part of China, including Inner Mongolia, Heilongjiang, Hebei, and Gansu, where the cool weather and isolation is desirable for virus-free seed potato cultivation. Thereafter, the general path of movement of seed potato tubers yearly within China is from north to south although, more recently, several provinces in the south such as Yunnan and Sichuan have established their own seed potato production locally at high elevations (56). Yunnan province now has $\approx 90 \%$ locally produced seed potato and $\approx 10 \%$ imported potato from northern China. A

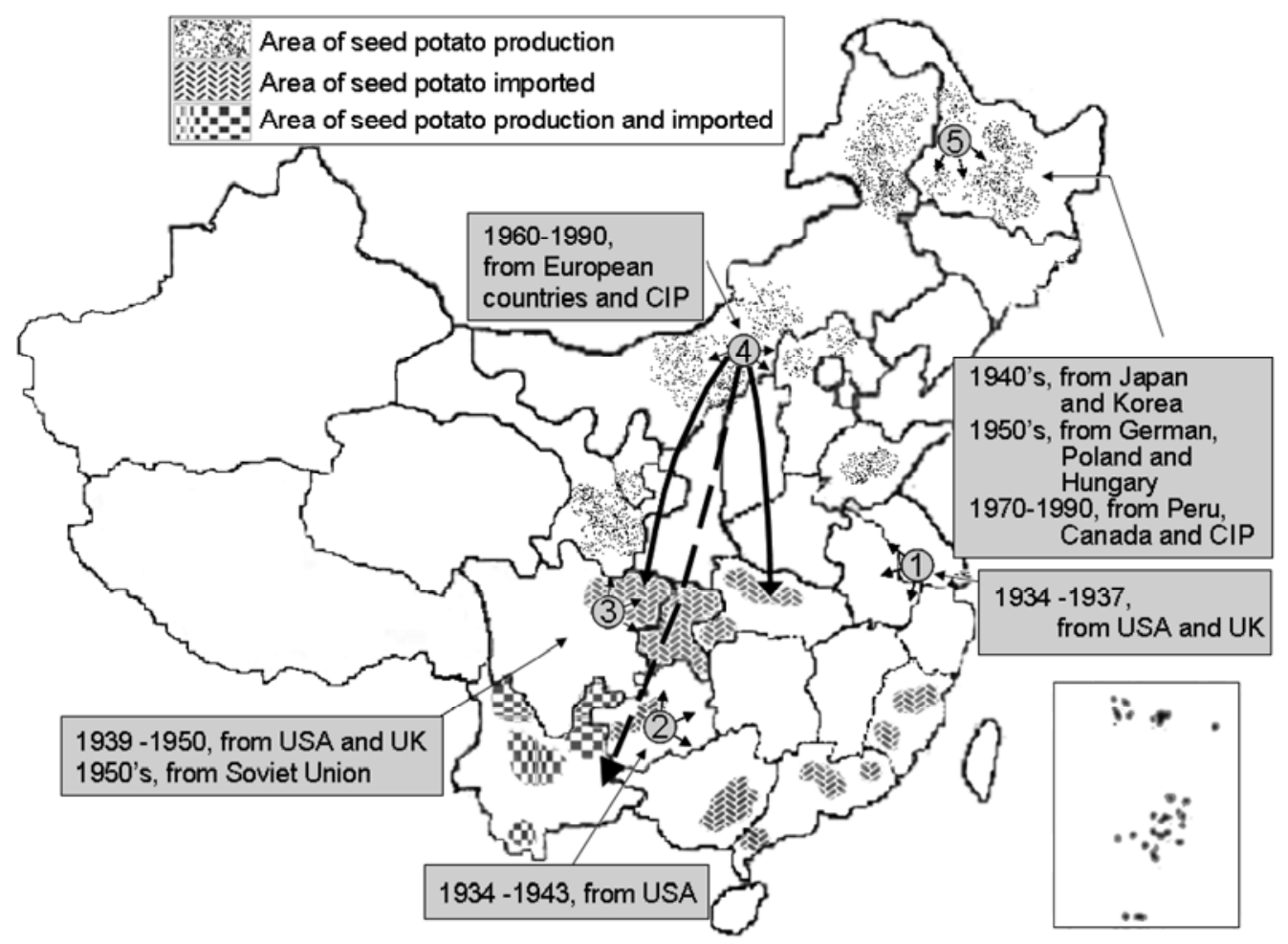

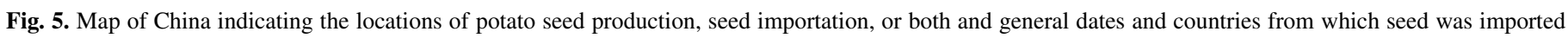

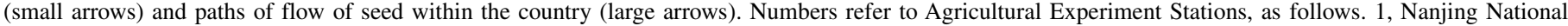

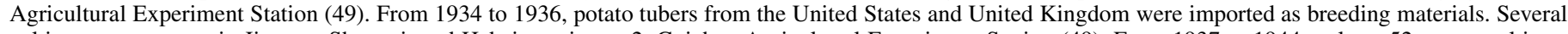

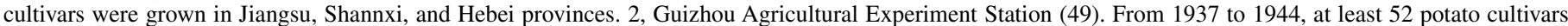

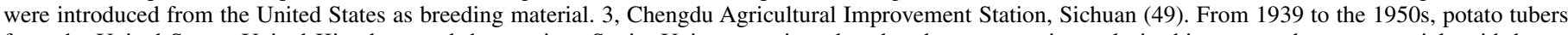

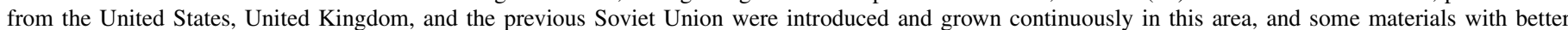

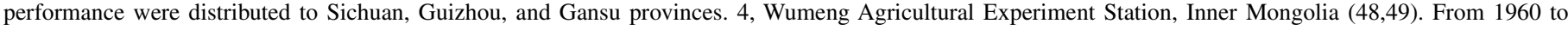

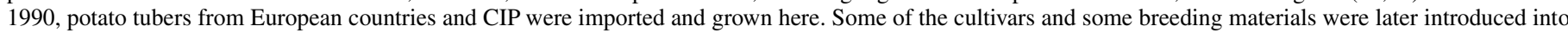



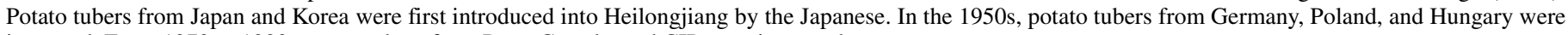
imported. From 1970 to 1990, potato tubers from Peru, Canada, and CIP were imported. 
large quantity of potato seed produced there are also exported to Vietnam and Burma. With increased growth of potato as a winter crop in south China provinces, SIB-1 has now dominated and is the main clonal genotype in that region. The migrations of potato tubers from north to south throughout China, some of which were infected with SIB-1, may have led to the wide distribution of SIB1 in China and is likely one of the major causes of resurgence of late blight in China.

Populations of $P$. infestans have undergone genetic changes because samples collected after 1999 contained fewer A2 isolates than was reported previously $(1,22)$. Moreover, reports from other labs recently have shown that the A2 isolates were not detected in areas where A2 mating types were reported earlier $(5,32,55,58)$. During our extensive survey of the mating type distribution of $P$. infestans in nine provinces in China, only a few isolates of A2 mating type were detected and only in Yunnan province. Asexual reproduction and dispersal of clonal lineages in seed is the predominant method of pathogen reproduction in most areas of China. However, because isolates of $P$. infestans from Yunnan province had the greatest number of different genotypes, further sampling in this region is in order. A few self-fertile isolates were found among A1 isolates in Yunnan (16). The potential for the pathogen to undergo sexual reproduction in Yunnan in the future should also be investigated.

Our data suggest multiple migrations of $P$. infestans into China. The Ia mtDNA haplotype was first introduced in the 1930s and still occurs but other mitochondrial lineages have also been introduced into the country over time. The Ib mtDNA haplotype was found in historic samples in China and other Asian countries after 1950, suggesting a second migration. Movement of seed potato tubers through the country has played a major role in the current dominance of the SIB-1 genotype throughout China, most likely via infected potato tubers from Russia and Japan. Populations of $P$. infestans are dynamic and displacement of genotypes and continued monitoring of the genetic structure, mating types, pathotypes, and fungicide sensitivity of isolates will be necessary in the future in China over wider areas of the country to both aid the late blight potato breeding programs and improve disease management.

\section{ACKNOWLEDGMENTS}

We thank G. Liu for technical support with RG57 fingerprinting. Part of this research was conducted during a sabbatical leave by L. Guo in the Department of Plant Pathology, North Carolina State University in 2006. Funding was provided by the National Natural Science Foundation of China (30270862) and the United States Department of Agriculture National Research Initiatives Competitive Grants Program Grant number NRI 2006-55319-16550.

\section{LITERATURE CITED}

1. Akino, S., Gotoh, K., Nishimura, R., Maeda, A., Naito, S., and Ogoshi, A. 2004. Comparison of Chinese and Japanese A1 isolates of Phytophthora infestans. J. Gen. Plant Pathol. 70:212-214.

2. Akino, S., Kato, M., Gotoh, K., Naito, S., and Ogoshi, A. 2005. Genetic relationships between the dominant genotypes of Phytophthora infestans in Hokkaido, Japan. J. Gen. Plant Pathol. 71:200-203.

3. Akino, S., Shirasaw, Y., Kondo, N., and Naito, S. 2008. N605ab, a specific molecular marker for Phytophthora infestans, distinguishes three genotypes in Japan. J. Gen. Plant Pathol. 74:125-127.

4. Avila-Adame, C., Gómez-Alpizar, L., Buell, R. C., and Ristaino, J. B. 2006. Mitochondrial genome sequencing of the haplotypes of the Irish Potato famine pathogen, Phytophthora infestans. Curr. Genet. 49:39-46.

5. Andersson, B., Widmark, A. K., Yuen, J. E., Nielsen, B., Ravnskov, S., Kessel, G. J. T., Evenhuis, A., Turkensteen, L. J., Hansen, J. G., Lehtinen, A., Hermansen, A., Brurberg, M. B., and Nordskog, B. 2009. The role of oospores in the epidemiology of potato late blight. Acta Hortic. 834:6168.

6. Carlisle, D. J., Cooke, L. R., and Brown, A. E. 2001. Phenotypic and genotypic characterisation of Northern Ireland isolates of Phytophthora infestans. Eur. J. Plant. Pathol. 107:291-303.
7. Carter, D. A., Archer, S. A., Buck, K. W., Shaw, D. S., and Shattock, R. C. 1990. Restriction fragment length polymorphisms of the mitochondrial DNA of Phytophthora infestans. Mycol. Res. 94:1123-1128.

8. Chang, T. T., and Ko, W. H. 1991. Factors affecting germination of oospores of Phytophthora infestans. J. Phytopathology 133:29-35.

9. Cooke, D. E. L., Young, V., Birch, P. R. J., Toth, R., Gourlay, F., Day, J. P., Carnegie, S. F., and Duncan, J. M. 2003. Phenotypic and genotypic diversity of Phytophthora infestans populations in Scotland (1995-97). Plant Pathol. 52:181-192.

10. Deahl, K. L., DeMuth, S. P., Linden, S. L., and Rivera-Pena, A. 1995. Identification of mating types and metalaxyl resistance in North American populations of Phytophthora infestans. Am. Potato J. 72:35-49.

11. Drenth, A., Tas, I. C. Q., and Govers, F. 1994. DNA fingerprinting uncovers a new sexually reproducing population of Phytophthora infestans in the Netherlands. Eur. J. Plant Pathol. 100:97-107.

12. Elansky, S., Smirnov, A., Dyakov, Y., Dolgova, A., Filippov, A., Kozlovsky, B., Kozlovskaya, I., Russo, P., Smart, C., and Fry, W. E. 2001. Genotypic analysis of Russian isolates of Phytophthora infestans from the Moscow Region, Siberia and Far East. J. Phytopathol. 149:605-611.

13. Food and Agricultural Organization. 2008. International Year of the Potato. http://www.potato2008.org/en/world/index.html.

14. Fry, W. 2008. Phytophthora infestans: the plant (and $R$ gene) destroyer. Mol. Plant Pathol. 9:385-402.

15. Fry, W. E., Goodwin, S. B., Dyer, A. T., Matuszak, J. M., Drenth, A., Tooley, P. W., Sujkowski, L. S., Koh, Y. J., Cohen, B. A., Spielman, L. J., Deahl, K. L., Inglis, D. A., and Sandlan, K. P. 1993. Historical and recent migrations of Phytophthora infestans: chronology, pathways, and implications. Plant Dis. 77:653-661.

16. Fyfe, A. M., and Shaw, D. S. 1992. An analysis of self-fertility in field isolates of Phytophthora infestans. Mycol. Res. 96:390-394.

17. Ghimire, S. R., Hyde, K. D., Hodgkiss, I. J., Shaw, D. S., and Liew, E. C. Y. 2003. Variations in the Phytophthora infestans population in Nepal as revealed by nuclear and mitochondrial DNA polymorphisms. Phytopathology 93:236-243.

18. Gómez-Alpizar, L., Carbone, I., and Ristaino, J. B. 2007. An Andean origin of Phytophthora infestans inferred from mitochondrial and nuclear gene genealogies. Proc. Nat. Acad. Sci. USA 104:3306-3311.

19. Goodwin, S. B., Drenth, A., and Fry, W. E. 1992. Cloning and genetic analyses of two highly polymorphic, moderately repetitive nuclear DNA's from Phytophthora infestans. Curr. Genet. 22:107-115.

20. Goodwin, S. B., Schneider, R. E., and Fry, W. E. 1995. Use of celluloseacetate electrophoresis for rapid identification of allozyme genotypes of Phytophthora infestans. Plant Dis. 79:1181-1185.

21. Goodwin, S. B., Smart, C. D., Sandrock, C., Deahl, K., Punja, Z., and Fry, W. E. 1998. Genetic change within populations of Phytophthora infestans in the United States and Canada during 1994-1996: role of migration and recombination. Phytopathology 88:939-949.

22. Gotoh, K., Akino, S., Maeda, A., Kondo, N., Naito, S., Kato, M., and Ogoshi, A. 2005. Characterization of some Asian isolates of Phytophthora infestans. Plant Pathol. 54:733-739.

23. Griffith, G. W., and Shaw, D. S. 1998. Polymorphisms in Phytophthora infestans: Four mitochondrial haplotypes are detected after PCR amplification of DNA from pure cultures or from host lesions. Appl. Environ. Microbiol. 64:4007-4014.

24. Guo, J., van der Lee, T., Qu, D. Y., Yao, Q., Gong, X. F., Liang, D. L., Xie, K. Y., Wang, X. W., and Govers, F. 2009. Phytophthora infestans isolates from Northern China show high virulence diversity but low genotypic diversity. Plant Biol. 11:57-67.

25. Guo, L. Y., and Ko, W. H. 1993. Two widely accessible media for growth and reproduction of Phytophthora and Pythium species. Appl. Environ. Microbiol. 59:2323-2325.

26. Guo, L. Y., Yang, Y. L., and Luo, W. F. 2002. Mating type and biological characteristics of Phytophthora infestans isolates from Yunnan, China. Acta Phytopathol. Sin. 32:49-54.

27. Guo, L. Y., and Zhu, X. Q. 2004. Variation in the Phytophthora infestans population as revealed by mitochondrial DNA polymorphism. Page 381 in: Proc. 15th Int. Plant Prot. Congress, Beijing.

28. Jacobson, D. J., and Gordon, T. R. 1990. Variability of mitochondrial DNA as an indicator of relationships between populations of Fusarium oxysporum f. sp. melonis. Mycol. Res. 94:734-744.

29. Jin, G. H., Yuan, S. K., Lv, W. H., Wen, J. Z., and Sun, X. M. 2006. Physiological race and mating type of Phytophthora infestans on potato in Heilongjiang Province (in Chinese). J. Northeast Agric. Univ. 37:610-614.

30. Jyan, M. H., Ann, P. J., Tsai, J. N., Hsih, S. D., Chang, T. T., and Liou, R. F. 2004. Recent occurrence of Phytophthora infestans US-11 as the cause of severe late blight on potato and tomato in Taiwan. Can. J. Plant Pathol. 26:188-192.

31. Lee, S. B., Milgroom, M. G., and Taylor, J. W. 1988. A rapid, high yield mini-prep method for isolation of total genomic DNA from fungi. Fungal Genet. Newsl. 35:23-24. 
32. Li, B. J. Chen, Q. H., Lv, X., Lan, C. Z., Zhao, J., Qiu, R. Z., amd Weng, Q. Y. 2009. Phenotypic and genotypic characterization of Phytophthora infestans isolates from China. J. Phytopathol. 157:558-567.

33. Li, C. H., Long, W. B., Yang, S. Z., Li, Y. H., and Sui, Q. J. 2003. Research of potato breeding and the potato industry development in Yunnan. Agric. Sci. Technol. Yunnan Suppl. :95-101.

34. Li, W., Zhang, Z. M., and Fan, M. Z. 1998. Resistance to metalaxyl in Phytophthora infestans populations in potato crops (in Chinese). J. Agric. Univ. Hebei 21:63-65.

35. Liu, J., Xie, C., Yuan, M., and Liu, X. 1993. Control of potato late blight with Ridomil. Potato late blight control in China. In: Proc. Workshop Kunming. China Agriculture Science and Technology Publisher.

36. Koh, Y. J., Goodwin, S. B., Dyer, A. T., Cohen, B. A., Ogoshi, A., Sato, N., and Fry, W. E. 1994. Migrations and displacements of Phytophthora infestans populations in east Asian countries. Phytopathology 84:922-927.

37. May, K. J., and Ristaino, J. B. 2004. Identify of the mitochondrial DNA haplotype(s) of Phytophthora infestans in historical specimens from the Irish potato famine. Mycol. Res. 108:171-179.

38. Mcleod, A., Denman, S., Sadie, A., and Denner, F. D. N. 2001. Characterization of south African isolates of Phytophthora infestans. Plant Dis. 85:287-291.

39. Nishimura, R., Sato, K., Lee, W. H., Singh, U. P., Chang, T. T., Suryaningsih, E., Suwonakenee, S., Lumyong, P., Chamswarng, C., Tang, W. H., Shrestha, S. K., Kato, M., Fujii, N., Akino, S., Kondo N., Kobayashi, K., and Ogoshi, A. 1999. Distribution of Phytophthora infestans population in seven Asian countries. Ann. Phytopathol. Soc. Jpn. 65:66-75.

40. Panabieres, F., Marais, A., Trentin, F., Bonnet, P., and Ricci, P. 1989. Repetitive DNA polymorphism analysis as a tool for identifying Phytophthora species. Phytopathology 79:1105-1109.

41. Ristaino, J. B., Groves, C. T., and Parra, G. 2001. PCR Amplification of the Irish potato famine pathogen from historic specimens. Nature 41:695-697.

42. Ristaino, J. B., and Hu, C. H. 2009. DNA sequence analysis of late blight populations gives clues to worldwide migrations. Acta Hortic. 834:27-40.

43. Rohlf, F. J. 2000. NTSYS-PC: Numerical Taxonomy and Multivariate Analysis System, Users Guide. Executer Publications, Setauket, NY.

44. Ryu, K. Y., Luo, W. F., Yang, Y. L., Guo, L. Y., Guo, H. C., Wang, Y., and Chen, H. R. 2003. Mating type, fungicide sensitivity and physiological race of Phytophthora infestans collected from Yunnan province. Acta Phytopathol. Sin. 33:126-131.

45. Shattock, R. C. 2002. Phytophthora infestans: Populations, pathogenicity and phenylamides. Pest Manage. Sci. 58:944-950.

46. Stukenbrock, E. H., and McDonald, B. A. 2008. The origins of plant pathogens in agro-ecosystems. Annu. Rev. Phytopathol. 46:75-100.
47. Sui Q. J. 2001. The strategy of potato breeding in China. Potato China 15:259-264. (In Chinese)

48. Tong, P. Y. 1990. The history of potato cultivation in China. China Hist. Mater. Sci. Technol. 11:10-19. (In Chinese)

49. Vega-Sanchez, M. E., Erselius, L. J., Rodriquez, A. M., Bastidas, O., Hohl, H. R., Ojiambo, P. S., Mukalazi, J., Vermeulen, T., Fry, W. E., and Forbes, G. A. 2000. Host adaptation to potato and tomato within the US-1 clonal lineage of Phytophthora infestans in Uganda and Kenya. Plant Pathol. 49:531-539.

50. Wang, W. Q., Ma, Z. Q., Zhang, X. F., Zhang, W. J., and David, M. 2002. Resistance to fungicides, mating types and fitness of Phytophthora infestans (in Chinese). Acta Phytopathol. Sin. 32:278-283.

51. Wang, Y. H., Guo, L. Y., Liang, D. L., and Zhu, X. Q. 2003. Mating type distribution and sensitivity to several chemicals of Phytophthora infestans from Inner Mongolia and Gansu Province, China. J. China Agric. Univ. 8:78-82.

52. Wangsomboondee, T., Trout Groves, C., Shoemaker, P. B., Cubeta, M. A., and Ristaino, J. B. 2002. Phytophthora infestans populations from tomato and potato in North Carolina differ in genetic diversity and structure. Phytopathology 92:1189-1195.

53. Xiang, W. N. 1957. Page 322 in: Chinese Reference on Mycology and Plant Pathology. Science Press, Beijing.

54. Xie, K. Y., and Wang, Y. 2001. CIP potato late blight research in China. J. Hebei Agric. Univ. 24:44-48.

55. Yang, S. X., Li, C. H., Hao, D. H., Gu, Z. L., and Chen, S. N. 2007. Phenotype characteristics of Phytophthora infestans on winter-growing potato in Dehong district of Yunnan province (in Chinese). Acta Phytopathol. Sin. 37:18-24.

56. Zhang, Z., Li, Y., Tian, S., Zhu, J., Wang J., and Song, B. 1996. Occurrence of potato late blight pathogen (Phytophthora infestans) A2 mating type in China. J. Hebei Agric. Univ. 19:62-65.

57. Zhang, Z. M., and Song, B. 1993. Review and outlook of late blight research in northern China. Pages 7-12 in: Proc. Manage. Late Blight China. China Agricultural Science and Technology Press, Beijing.

58. Zhao, Z. J., Cao, J. F., Li, C. H., Sun, D. W., Yang, M. Y., and Wang, J. 2007. Characteristics of mating type, metalaxyl sensitivity, mtDNA haplotype and succession of Phytophthora infestans populations in Yunnan, 2000 to 2003 (in Chinese). Sci. Agric. Sin. 40:727-734.

59. Zhu, X. Q., Che, X. B., Guo, L. Y., and Wang, Y. H. 2004. Mating type and sensitivity to several fungicides of Phytophthora infestans from six provinces (cities) in China. Plant Prot. 30:20-23. (In Chinese)

60. Zhu, X. Q., Wang, Y. H., and Guo, L. Y. 2006. Genetic diversity revealed by RAPD Analysis among isolates of Phytophthora infestans from different locations in China. Acta Phytopathol. Sin. 36:249-258. 